\title{
Industrial relations, occupational safety and health, and union organising in Australia: lessons and opportunities
}

\author{
Michael Barry BCom (Hons) PhD, Griffith University, Australia, and \\ Rebecca Loudoun BA BCom (Hons) PhD, Griffith University, Australia
}

\begin{abstract}
This paper examines the intersection between recent changes in industrial relations legislation and union involvement in health and safety in Australia. Of specific interest is how unions prioritise occupational safety and health concerns against other workplace issues that often form the basis of union campaigns. During this examination, claims that unions can use health and safety as an organising tool are evaluated from data collected in interviews with union officials based in regional and metropolitan centres in Q ueensland, A ustralia. O ur evidence supports the view that unions have much to gain by focusing on members' health and safety concerns, especially in an environment where union protections have been systematically weakened under industrial relations regulations. However, we also found that organising efforts around occupational safety and health remain isolated, with most unions continuing to focus on member interests within the realm of mainstream industrial relations.
\end{abstract}

Key words

Industrial relations, organisation of work, policy, regulation, structure of work, trade union organising strategies, trade union renewal, worker representation

\section{Introduction}

The regulation of occupational safety and health $(\mathrm{OSH})$ in Australia is caught between two competing tendencies. On the one hand, state-based health and safety legislation guarantees employee representation and is heavily influenced by the 'R obens' self-regulation approach to $\mathrm{OSH}$ management. $\mathrm{On}$ the other, anti-union legislation in the field of industrial relations places severe restrictions on many union rights and protections that have traditionally facilitated effective employee representation over a wide range of matters, including $\mathrm{OSH}$. While in other jurisdictions, such as the UK and $\mathrm{N}$ ew Zealand, anti-union legislation has been rolled back under current Labour governments to at least enable a return to statutory union recognition, in A ustralia a decade of harsh employment relations regulation is set to become much tougher with the introduction of the government's 2006 WorkC hoices legislation. The legislation further erodes union rights and protections, and will inevitably lead to increased insecurity and precariousness of employment.

Given such a context, this study examines how unions in one Australian state, Q ueensland, view their role in $\mathrm{OSH}$ alongside other union activities. In view of the disparity between the $\mathrm{OSH}$ and industrial relations regulatory environments, the study explores the attitudes of union officials to the possibility of using health and safety as a means to not only educate workplace $\mathrm{OSH}$ representatives, but also to develop OSH awareness into a potential union organising tool.

The first part of the paper briefly details the legislative framew ork for managing health and 
safety in Australia, particularly as it relates to unions. Industrial relations legislation is also examined, along with changes in the work environment more broadly. These developments provide the backdrop for a project designed to examine union representation and organising activities around $\mathrm{OSH}$. Data from this project are presented in the second part of the paper. In the third section we interpret the data in light of the recent regulatory changes in industrial relations that restrict union rights and activities. In this section we assess the potential for unions to develop organising strategies in the area of $\mathrm{OSH}$, where the statebased legislation provides more favourable protections for unions.

\section{Background: discordant regulatory systems}

As in most advanced market economies, there have been significant changes made to OSH legislation in A ustralia over the past two decades. Each state and territory has progressively introduced a single Act (eg the Workplace H ealth and Safety Act 1995 in Q ueensland), which covers all workers and provides a structural framework for the management of OSH. Each Act outlines the primary (common law) duty of care of employers, and provides a number of other prescriptions regarding the management of $\mathrm{OSH}$. The Acts are intended to encourage employers and employees to monitor health and safety performance in the workplace through joint health and safety committees and employee-elected health and safety representatives. ${ }^{1}$

This model, which relies heavily on self-regulation, was premised on an assumption drawn from the influential 'Robens' reforms, namely that employers and employees share a commonality of interest in $\mathrm{OSH}$, making it efficacious to collaborate on health and safety issues in the workplace. ${ }^{2}$ As part of the mechanisms designed to facilitate this collaboration, workers have legislated rights in most states to elect one (or more, as a result of negotiating with their employer) workplace health and safety representative (W H SR ).

Where unions have members in a workplace, the union can, if requested, conduct the election of WHSR s for all workers and represent workers in negotiations over:

- the number of representatives and their area of representation

- the extent of involvement by the employer in the election of representatives

- the intervals at which a representative is entitled to conduct inspections

- access to relevant training for representatives.

There is little doubt that the legislation has been successful in promoting collaboration over health and safety. Evidence indicates that $\mathrm{OSH}$ is one of the primary issues about which participation occurs in most workplaces, ${ }^{3}$ with over 30,000 health and safety representatives in Australia in the mid-1990s. ${ }^{4}$ H owever, this model was also premised on a certain political configuration between the major industrial relations parties, which included a well-organised trade union movement with clear recognition, and rights to bargain over $\mathrm{OSH} .{ }^{5} \mathrm{O}$ wing to developments in industrial relations legislation, this political configuration has changed dramatically in the past decade. It is now less clear whether workers and their representatives are well equipped to participate in negotiations about $\mathrm{OSH}$, which require a thorough understanding of the full range of potentially complex health and safety issues affecting their workplace, and also a capacity to negotiate effectively.

Since the late-1980s, federal governments have progressively eroded Australia's traditional state-sponsored system of compulsory conciliation and arbitration of pay and working conditions by enabling a system of enterprise- or workplace-level bargaining. The process of 
decentralising bargaining and the relaxation of third party arbitral intervention initially proceeded under Labor governments (who continuously held power between 1983 and 1996) that sought to modernise the Australian economy by a series of measures including increased labour market flexibility, with policy prescriptions that nevertheless retained key protections for organised labour.

From 1996, the pace of industrial relations change accelerated following the election of the current Conservative coalition government. Under its 1996 Workplace Relations Act (WRA), the coalition sought measures to reduce the regulatory influence of the A ustralian Industrial Relations Commission (the federal arbitration tribunal) and limit the market and organisational power of unions.

The WRA envisaged a bargaining process that primarily involved employers and employees within a single enterprise, with little involvement from unions or the arbitration system. ${ }^{6}$ In particular, through a process of 'award simplification', the government limited the parties' recourse to arbitration by allowing only 20 matters to be included in arbitration awards. M eanwhile, specific W RA changes that undermined the traditional influence of unions included:

- the introduction of freedom of association provisions that certain employers relied on to attempt to de-unionise workplaces

- the removal of union preference clauses from awards and agreements

- the emergence of non-union collective bargaining

- the introduction of a new (statutory) stream of individual bargaining known as Australian Workplace Agreements

- restrictions on union industrial action, including provisions that required notice for industrial action and limited the ability of unions to initiate 'protected' industrial action.

The introduction in 2006 of the government's WorkChoices regime will further weaken the influence of unions and break down the few remaining pillars of the arbitration system. Under WorkChoices, the number of 'allowable' award matters has been reduced to leave only five so-called 'community standards' covering wages, working hours and leave entitlements. $M$ eanwhile, the arbitration tribunal has lost its power to determine minimum wages for low paid workers. As discussed below, WorkChoices increases the already stiff impositions placed on union activity and industrial action, and adds significantly to the level of difficulty unions face in attempting to represent their members and organise new unionists. WorkC hoices also explicitly promotes bargaining instruments that enable the growth of individualised employment.

These legislative developments have occurred at a time when changes to the structure of the labour market not only place more workers beyond the reach of unions but also weaken the capacity of workers to safeguard their own health and safety. ${ }^{7}$ Anti-union legislation serves to compound the difficulties that unions face as a result of labour market restructuring that has seen massive job losses in areas of traditional union strength and the emergence of new types of casualised or precarious employment in which unions find it difficult to organise. During the 1990s, labour market restructuring, the loss of traditional legislative protections, and mounting union resistance from employers led to a sharp reduction in union density. ${ }^{8}$ The result of these factors is that many workers who might seek representation for a range of reasons find it increasingly difficult to access unions and vice-versa. In other words, in A ustralia, as in other countries, a substantial employee 'representation gap' now exists. ${ }^{9}$ 
These changes to the structure of the labour market have significant implications for the management of health and safety. The decline in unionisation alone poses a major challenge for the promotion of effective $\mathrm{OSH}$ for, as mentioned, the Robens approach to the management of $\mathrm{OSH}$ relies on effective worker representation. As Johnstone, Quinlan and Walters point out, the growth of non-standard employment presents an additional policy challenge, as these new categories of workers are not adequately covered by existing provisions contained within the state health and safety Acts that enable worker health and safety representation. According to these authors: ${ }^{10}$

... this shift poses a significant challenge for $\mathrm{OSH}$ legislation designed on a presumption of employment relationships and a level of unionisation that are now no longer the norm.

The reduced capacity of unions to be involved in health and safety at the enterprise level is also problematic for the management of health and safety because weakening unions further reduces the power of employees in the bargaining process. Without unions, employees are likely to form a poorly organised collective bargaining party and perhaps, more importantly, one that is less informed. One of the major functions of unions is to act as a source of information for workers on $\mathrm{OSH}$ issues. ${ }^{5}$ A nother function is to give employees a 'voice' to raise grievances with management. ${ }^{11}$ These functions are important because evidence indicates that workers often lack the requisite skills to identify and act on $\mathrm{OSH}$ hazards arising from changes in work practices and management techniques. ${ }^{12}$ There is also considerable evidence suggesting that trade union involvement has a significant impact on guiding the process used to decide on health and safety issues. ${ }^{13}$

$\mathrm{H}$ ere, the role of unions in the monitoring and enforcement of workplace health and safety needs to be considered. Historically, the role of unions in enforcement has been seen as crucial because of the limited resources of the government inspectorate. ${ }^{5}$ This has become even more problematic in Australia and other industrialised countries in recent years as public expenditure on $\mathrm{OSH}$ has continued to decline. ${ }^{14} \mathrm{M}$ oreover, with the decline in unionisation and rise in managerialism that has occurred in a range of countries, the consequent focus on workplace productivity has seen a decline in OSH standards. ${ }^{15}$

Given all of the factors that have weakened unions, there is a disparity between the industrial relations regulatory framework and the effective enforcement of workplace health and safety. While OSH legislation relies on the involvement of employee representation as well as various government bodies in setting and monitoring OSH standards, industrial relations legislation now actively discourages third party involvement - particularly union involvement - in the workplace. A reflection of this disparity is the lack of discussion within the policy debate on how $\mathrm{OSH}$ fits into the new industrial relations system. ${ }^{16}$

As the economic, policy and legislative environment that unions confront continues to provide more difficulties than opportunities, what role does $\mathrm{OSH}$ play in union campaigns to organise and represent workers? W ith some notable exceptions ${ }^{17}$ there is a curious gap in the research on the OSH implications for trade union revitalisation. As Fairbrother ${ }^{15}$ notes, OSH does not figure at the for efront of struggles in the workplace in the same way that questions concerning pay and related working conditions do. In the rapidly mushrooming literature on trade union renewal, there is almost no mention of the role of $\mathrm{OSH} .{ }^{10}$

D espite this apparent lack of research interest, there would appear to be considerable scope for exploring opportunities for unions to organise around OSH. This view has theoretical 
justification, for in an important revision to industrial relations theory, K elly ${ }^{18}$ argues that a clear link exists between the identification of a collective interest or injustice and the mobilisation of individuals into collective actors. M ost employees regard $\mathrm{OSH}$ as a legitimate arena for union involvement ${ }^{19}$ and consider $\mathrm{OSH}$ among their major concerns at work. ${ }^{15,20}$ Since unions in Australia, as in the majority of industrialised economies, have a legislated role in representing their members in worker elections for WHSRs, they have an opportunity to organise by promoting $\mathrm{OSH}$ as a legitimate industrial relations matter. An important research question for this project is whether unions are currently capitalising on this opportunity.

In an environment that produces many competing demands, OSH may not be prioritised by management, unions or workers to the extent necessary to achieve improvements in workplace health and safety standards. If workers prioritise other concerns about their working conditions ahead of $\mathrm{OSH}$, resources for $\mathrm{OSH}$ may not be readily available to union officials. By default, $\mathrm{OSH}$ may then become, as suggested by a very senior A ustralian union official, the 'poorer cousin' to other demands on unions' scarce resources. ${ }^{21}$ Thus, even though legislative changes in $\mathrm{OSH}$ may offer opportunities for unions to play a greater role in the workplace, they may not be well placed to do so.

\section{Method}

The data reported in this paper are drawn from interviews with union officials in Queensland, A ustralia. Participants were selected for the research using the following process. First, a list of all state-based unions registered with the Q ueensland Industrial Relations Commission was generated. This list was reduced to include only unions that represented members covered by the Q ueensland Workplace H ealth and Safety Act 1995. These restrictions resulted in a list of 36 unions, 14 of which were randomly chosen to participate in the research. Eleven unions agreed to take part. The three unions that declined did so for reasons unrelated to the aims of the research, such as internal restructuring.

Where it was identified that the union had a head office and branches or officials in regional Q ueensland areas, interviews were conducted with officials in Brisbane and in two other locations in an attempt to corroborate the views of one interviewee against another. This approach was chosen because Q ueensland is a particularly large and highly decentralised state, which could present different challenges for union officials operating in different locations. Although the influence of geography was not a specific interest of this study, it was important to ensure that the responses of union officials were representative of officials operating in potentially different work environments. Regional offices included those located in N orth Q ueensland (such as Cairns and Townsville) and areas closer to Brisbane, such as Ipswich and Bundaberg. Any variations in the responses of union officials in different regions are mentioned in the findings where appropriate.

The final mix of unions represented workers in most of the key sectors of Q ueensland industry, including:

- food processing

- light and heavy manufacturing

- emergency services

- trades

- retail

- finance

- education. 
While the sample was not intended to be fully representative of all unions that operate in Q ueensland, it did include a balance of large, medium and small unions, representing workers in a mixture of strongly and weakly unionised workplaces, and with members who were both white collar and blue collar workers. While the study included a blend of unions with members in privately and publicly owned workplaces, the latter were over-represented in the sample.

Face-to-face interviews (in all except one case, which was a telephone interview) were conducted between $M$ arch and December 2005. A semi-structured schedule was used for the interviews; it was pilot tested with officials from two unions in Brisbane before the main round of interviews. The interview schedule consisted of a series of open-ended questions asking respondents' views on:

- whether unions were using OSH as an organising tool

- whether union officials were considering the possibilities for organising around OSH

- what obstacles might prevent unions from organising around OSH matters should they wish to do so.

\section{Findings}

OSH and union organising: the reality

The interviews with union officials suggest that there is a very low level of organising activity centred around $\mathrm{OSH}$ in most unions in Q ueensland, and little awareness of the potential of $\mathrm{OSH}$ to be used as an organising tool. Consistent with the studies cited earlier, one of the major reasons for this was that most officials did not give OSH concerns the same level of priority as other mainstream industrial relations issues. Furthermore, most of the unions in our survey did not promote the importance of OSH in their direct contact with their members or through the information they sent to them.

Although eight unions placed $\mathrm{OSH}$ information in their journals, this information appeared to be something of a token gesture. Two unions informed members of O SH issues through training, one informed members through occasional seminars and four informed members by email. O nly two unions mentioned that they supply $\mathrm{OSH}$ information on their website. This activity around $\mathrm{OSH}$ can best be described as ad hoc and undeveloped, and suggests that unions do not use a deliberate strategy to educate and recruit around $\mathrm{OSH}$.

The situation was marginally different in industries such as heavy manufacturing, where members face obvious O SH risks and unions are aware that their members consider OSH as important. Unions with members in these industries were more actively involved in O SH. For example, one union with workers in a particularly hazardous industry sent a newsletter to members by email and fax. This union also sent members safety alerts in relation to particularly dangerous hazards. N onetheless, like all others in the survey, these unions did not send any specific information on $\mathrm{OSH}$ to new members.

O nly one union official reported that OSH was used explicitly as an organising tool. The strategy this union adopted to promote organising around $\mathrm{OSH}$ was to provide its organisers and delegates with $\mathrm{OSH}$ training and professional development, and encourage delegates to join workplace OSH committees. In the words of the official interviewed, they try to give members 'ownership of an $\mathrm{OSH}$ issue'. The officials of other unions also stated their desire to empower workers to deal with OSH issues in the workplace without the involvement of the 
union. These officials, however, used this strategy as a means to manage scarce resources (ie to relieve the official from having to deal with $\mathrm{OSH}$ issues) rather than as a strategy to educate and recruit around $\mathrm{OSH}$.

OSH and union organising: the potential

From our interviews, eight unions said that they had members join the union because of health and safety reasons, indicating that successful recruiting had occurred even without unions promoting $\mathrm{OSH}$ or using it explicitly as an organising tool. However, only two interviewees explained that they might look at how to use OSH issues to strengthen the union. Typical of the view of the vast majority of unions was that only an issue that affects everyone will be used as a recruiting tool. As one union officer stated: 'If the OSH issue is critical, they [the members] will escalate the action to resolve it.' A nother union official said that an organising issue would be 'member driven', and that 'a good issue will build strength for the union'. H ow ever, bringing OSH issues to the attention of officials as a collective grievance seems difficult, given that many officials noted that members had a low level of awareness about OSH issues, particularly those that are more insidious and bound up in the organisation of work. Unions with members in regional areas were more obviously affected in this regard. This was illustrated by an official of a Brisbane-based union, who commented that there is 'not a lot of OSH from members in regions', and by an official of a regional union, who stated that 'the members need to be educated'.

OSH and union organising: the obstacles

The findings presented so far suggest that the $\mathrm{OSH}$ activities of unions may be limited by members' demands. That is, if members do not bring OSH issues to their union, this lack of demand for suitable resources may result in the union putting resources into non-O SH issues that members do bring to the attention of officials. In many ways the evidence points to a vicious cycle, whereby:

- unions only act on issues brought forward by members

- members are reluctant to bring forward problems because they are unaware that they are related to $\mathrm{OSH}$

- unions are cautious about investing valuable resources in $\mathrm{OSH}$ concerns because they appear to occur on an individual rather than on a collective basis.

If a vicious cycle exists around a lack of information, awareness and resourcing of OSH within unions, what, if any, strategies might unions use to break this cycle? O ne possibility would seem to lie in unions building the knowledge and skills base of officials in the area of $\mathrm{OSH}$ so that they are able to identify workplace OSH risks where members themselves are not educated about 'what OSH is'. In other words, officials may not identify a need for resources because of their lack of knowledge about some aspects of OSH or because members do not bring those particular issues to the union. As noted by one official:

Some organisers are good organisers but not educated on industrial relations and OSH and vice-versa.

To some extent, $\mathrm{OSH}$ must be driven by union members or WHSRs. If there are no representatives, and/or members lack knowledge of industry hazards and risks, these issues will not be brought to the union unless officials are able to access the workplace, identify the risks on site, and impart that knowledge to members directly, or in some other way, eg through contact with delegates or in union journals. 
A good example of an identifiable OSH issue that is often not brought to the attention of union officials is stress. A number of the unions that participated in the study regarded stress as an important issue. Some of them represent members in industries that are inherently dangerous, and where stress is a known hazard in the industry. Despite this, members would not bring their concerns about stress to their union. In one such case, the official cited the 'macho attitude of most members' as 'a big hurdle', resulting in some members having the attitude 'I'm a big boy. I don't need to go to the union. I can handle it myself'. Emerging and growing issues - such as stress, bullying and employment equity, which are now being recognised for their $\mathrm{OSH}$ effect on worker ${ }^{22}$ - will require union resources, which may not be quantifiable. M oreover, since these issues often present themselves as individual cases, they have the potential to consume valuable union resources but not necessarily appear to build enough momentum to become an issue around which the union can organise. As one official put it:

There is a general lack of interest about O SH from head office. They think that the only issues people in [this] sector face are work intensification and stress, and they are dealing with these things in an industrial arena. This is common to most white collar unions where, unlike blue collar workers, members do not face overt OSH risks every day. It is a cop out, though, as one only has to dig a little deeper to see that risks are present. Higher level organisers focus on other issues such as enterprise bargaining structures because they are easier to make members see that they are doing something for them.

M ost officials interviewed were aware of the need for more resources in $\mathrm{OSH}$. When asked what resources would help them do their job, 15 interviewees identified more access to O SH information, training and education. Exploring this issue further, one official said that 'We need more capacity to identify issues'. He explained that if the union could have more formalised education for organisers and delegates, they could identify issues better. He argued that:

... hazards such as broken air-conditioning and fire alarms are more easily identified as issues, compared to other hazards like violence and bullying. The union needs more resources on how to organise against psychiatric damage like violence, overwork, bullying and work intensification.

Although the first step in breaking the cycle lies with knowledge and skills development for officials, another means would seem to lie in educating members about hazards and risks in their industry, and empowering them to act on their concerns. O ne way this could be done would be to make better use of the rights associated with WH SRs.

The rights that OSH legislation provides WH SR s with may enable unions to develop organising strategies around $\mathrm{OSH}$ issues. If unions focused more on the election and training of WHSRs, especially in regional areas, union members would gain knowledge from completing WHSR training. Also, through WHSRs, OSH information can be easily disseminated to other members in the workplace. Yet the majority of unions within our study do not use their rights in the areas of organising and recruiting. Despite having a legal right to be involved in the election of WHSRs, less than half the officials in our study indicated that their union took advantage of this right. The unions that were involved in their election were those within the survey that had the larger memberships (the only exception being the union with the largest overall membership). Clearly this is an area where unions are missing a valuable opportunity, and can become more active. 
This is not to suggest that improving the skills and knowledge base of officials, and using $\mathrm{OSH}$ training for $\mathrm{OSH}$ representatives as an organising tool, is an easy endeavour. There can be no doubt that logistical and resourcing obstacles exist for many unions, particularly the small unions and those operating in regional locations. O ne regional union official identified the limited provision of union training in regional areas as a problem, claiming that it stemmed from a lack of available staff to cover people taking time off from their normal work. Indeed, it was common for unions to have only one or two officials in their regional offices. Cost is also an issue in regional areas, as employers pay for the course, accommodation and living expenses for workers if they cannot attend a training course in their own region. $\mathrm{N}$ onetheless, these difficulties should not prevent unions from exploring the possible benefits that can be gained from placing valuable resources into $\mathrm{OSH}$ training and education.

To summarise, this study highlights a lack of union involvement across a range of O SH -related activities, which limits their ability to monitor and enforce health and safety standards and potentially recruit new members. These activities are summarised below. Although a minority of unions indicated that they performed some of these activities, no unions performed all of them and many unions performed none. Specifically, most unions did not:

- provide new and existing members with information about OSH

- have strategies in place to enable delegates and members to identify OSH issues in the workplace

- actively participate in the election of WHSRs, and participate in negotiations over the number of WHSRs, their areas of representation, and other related issues

- provide ongoing $\mathrm{OSH}$ training for officials and members

- provide their officials and members with substantial OSH information and resources.

Discussion: OSH and union organising in a cold industrial relations climate Studies of effective joint $\mathrm{OSH}$ management demonstrate an important intersection between the role of unions in the regulation of the employment relationship and their role in supporting workplace representatives in the regulation of $\mathrm{OSH}$. In particular, joint $\mathrm{OSH}$ management appears to work most effectively where it is supported by, among other things: ${ }^{23}$

- legislative provisions for worker representation, actively supported by regulatory inspectors

- worker organisation in the workplace that prioritises OSH and integrates it with other aspects of representation on industrial relations

- support for workers' representation from trade unions outside workplaces, especially in the provision of information and training.

As Walters observes: ${ }^{20}$

... where worker representatives are supported by trade unions directly or indirectly, they are more likely to be able to engage meaningfully and autonomously in the dialogue with employers that is essential to self-regulation.

The substantive evidence which suggests that unions have a key role to play in the effective management of $\mathrm{OSH}$ by supporting those employees who directly represent the $\mathrm{OSH}$ interests of workers sits uncomfortably with legal developments in industrial relations that erode the rights of unions to represent workers and to access workplaces to conduct legitimate union business, including $\mathrm{OSH}$. 
Indeed, in Australia, since the election of a Conservative coalition government in 1996, unions have faced a very hostile industrial relations environment. Following the introduction of the Workplace Relations Act 1996, industrial relations changes have both curtailed traditional union rights and protections and, at the same time, systematically strengthened the rights and protections for employers. While statutory prohibitions restrict an ever-increasing range of union activities, and are backed by higher penalties, employers face very few restrictions. For example, under the 2006 WorkChoices legislation, employers remain relatively free to initiate collective bargaining lock-outs, whereas unions are prohibited from engaging in industrial action unless they first hold a secret ballot of at least 50 per cent of employees and a majority vote in support of the industrial action. As well as creating logistical difficulties and slowing the process of initiating industrial action, there are increased powers to terminate or suspend the bargaining period in cases where the M inister deems that the industrial action is causing, or would cause, harm to a part of Australia, or even if it would 'adversely effect' an employer. ${ }^{24}$ These WorkC hoices restrictions further tighten the already onerous conditions under which unions may initiate industrial action by providing, for example, that:

- legal action can only be taken over issues immediately pertaining to the employment relationship

- legal action can only occur during a designated 'bargaining period'

- unions must provide notification of the dates and duration of industrial action in many instances

- unions are prohibited from taking industrial action to promote pattern bargaining.

WorkC hoices also indirectly increases the level of difficulty unions face in attempting to represent their members and organise new unionists. For instance, individual agreements prevail over collective agreements at all times. This gives greater scope for employers to seek to individualise, or move, employees from employment relationships to common law contracts, so as to limit protections accorded to employees and/or avoid unionisation..$^{25}$ Under WorkChoices, the existing employer exemption from unfair dismissal protection has also been widened to include all firms employing fewer than 100 employees. The unfair dismissal exemption was first introduced by the coalition as a protection only for small businesses and was previously limited to firms employing fewer than 15 workers. In small and medium-sized firms, employees will now have more reason to fear raising issues, such as health and safety concerns, in an environment where employers need to provide no justification for dismissals. International studies demonstrate clearly that downsizing and organisational restructuring, and their associated practices such as work intensification and coercive management, have led to increased employee mental illness, stress and anxiety. ${ }^{26}$ Greater employment insecurity in all its forms, including through the removal of dismissal protection, can be added to the considerable evidence of the negative impact of various types of precarious employment on the incidence and reporting of O SH risk. ${ }^{27}$ $\mathrm{H}$ ere again the WorkC hoices legislation presents difficulties for $\mathrm{O} \mathrm{SH}$ regulation inasmuch as it gives much greater scope to employers to move employees away from the traditional protections of the award and enterprise bargaining systems, and re-employ them on statutory or common law individual contracts, or as independent contractors.

Of particular importance to employee representation in $\mathrm{OSH}$ are provisions in the legislation that severely restricts union access to the workplace. The new regulations require union officers to provide 24 hours' notice to access or inspect breaches. If union officials wish to discuss a breach caused by an employer, they must notify the employer and formally request to see records. Such a request cannot be reasonably refused. H owever, in relation to access for the purposes of discussing union business (eg organising), the restrictions are particularly onerous. 
Union officers must again provide 24 hours' notice to be admitted, however they may then be excluded from the workplace for 'excessive' activity or 'for any other reason'. These provisions give managers broad scope to expel union officials if they do not like the way they are conducting their business.

The aforementioned developments in state intervention affecting industrial relations point to a need for unions to develop alternative strategies to organise and mobilise members. It is here, somewhat paradoxically, that health and safety represents a unique opportunity for unions. As union rights and protections have been systematically eroded under the federal industrial relations legislation, the rights to represent workers over health and safety matters that are contained in state-based health and safety Acts become an increasingly important protection, and possible organising tool. In this respect, the separation of industrial relations and health and safety regulations in the Australian system is now a distinct advantage for unions. Thus, union officials have the ability to use the more sympathetic state-based health and safety regulations as a mechanism to trigger access to members, and to promote awareness of, and involvement in, union business. Indeed, because of the strictures imposed by WorkChoices on access and right of entry, the $\mathrm{N}$ ew South Wales Labor government moved to amend its state health and safety Act to extend the rights of employee representatives to access workplaces. Under draft amendments: ${ }^{28}$

An authorised representative of an industrial organisation of employees may enter any premises the representative has reason to believe is a place of work where members of that organisation (or persons who are eligible to be members of that organisation) work for the purpose of discussing matters relating to occupational health and safety.

Given the apparent opportunities provided under state-based OSH legislation, it is critical that unions understand how to address workers' health and safety concerns, and how to turn those concerns into campaigns to build union membership and strength. And yet, as previously mentioned, $\mathrm{OSH}$ is conspicuous in its absence from the considerable industrial relations literature on trade union renewal, and from the discussions of those within the union movement itself who are debating union renewal. ${ }^{20}$ From our data, and available secondary sources, it appears that at least some union officials are getting this message. H owever, our data also suggest that union interest in promoting awareness around health and safety has a strong positive relationship to officials' perceptions of serious OSH risk. In other words, unions operating in industries that expose workers to hazards that produce serious injury and death are those most interested in promoting $\mathrm{OSH}$ awareness, and possibly organising around $\mathrm{OSH}$ matters.

This perception needs to change to align with contemporary views of the nature and origin of work-related injuries and illnesses, and before unions can use state-based health and safety legislation to their advantage. To an increasing extent, commentators and policy-makers alike are taking a broader, more holistic view of OSH that encompasses musculoskeletal disorders and stress-related complaints that are linked to the design of organisational structures and work processes such as work intensification and work scheduling. ${ }^{29}$ This wider view merges the more established technical aspects of $\mathrm{OSH}$ with aspects of work organisation traditionally considered in an industrial relations arena. Accordingly, it increasingly implies a relationship to the control of the organisation of work requiring union engagement. ${ }^{30}$

Even if trade union leaders are not building OSH awareness to promote union renewal, they need to be aware of the importance of external union involvement as a means to make worker representation in $\mathrm{OSH}$ more effective. Unions will not be serving their members' interests if they 
do not consider the importance of OSH and seek to equip WHSRs, whether or not they are union members or delegates, with the training and resources they need to execute their responsibilities.

\section{Conclusions}

A cademic commentators are increasingly beginning to question whether the artificial separation between the role of social partners in the management of industrial relations and $\mathrm{OSH}$ can usefully continue. The limitations of the analytical distinction between industrial relations and O SH have been made apparent by authors such as Q uinlan, $\mathrm{H}$ asle and Walters. These authors argue that changes to the structure of the labour market create new OSH risks, such as stress and bullying, particularly because labour market changes have produced a rise in employment insecurity and a greater work intensification. These and other authors point out that evidence clearly supports the view that improvements in $\mathrm{OSH}$ standards require the involvement of the direct parties and their representatives. In particular, external union involvement is linked to improved OSH performance. Therefore, scholars who are interested in the nexus between effective $\mathrm{OSH}$ and industrial relations regulation lament the difficulties of improving $\mathrm{OSH}$ systems and regulations at a time when changes to the regulation of the employment relationship promote decentralised bargaining and individualisation, and therefore make external employee representation more and more difficult.

A further disappointment is the apparent lack of awareness of the potential for unions to become more actively involved in $\mathrm{OSH}$, not only to serve the existing and emerging $\mathrm{OSH}$ needs of their members, but also to use $\mathrm{OSH}$ as a strategy for union renewal. As mentioned, the paucity of evidence of $\mathrm{OSH}$ forming a basis for union organising is a limitation in the considerable literature devoted to understanding and addressing the decline in unionisation, and the strategies unions can adopt for renewal. If the literature on union renewal does not offer insights into opportunities that can be generated around $\mathrm{OSH}$, this is consistent with the findings of our study, which also highlight a lack of awareness among union officials of how OSH can be used to build awareness of the role of unions among potential and existing members. This is particularly the case as $\mathrm{OSH}$ regulations can give unions a strong ongoing presence in the workplace by virtue of the rights unions have to be involved in the election of health and safety representatives. Unions then have strong incentives to use OSH to circumvent anti-union provisions in industrial relations regulations, particularly in the current regulatory environment that prescribes a very limited range of permissible union activities.

In highlighting an apparent lack of awareness of these opportunities, our study also indicates a very real opportunity for unions to make use of the more favourable provisions for employee representation in the health and safety regulations to maintain access to workplaces and to build momentum around common OSH grievances so as to promote organising. However, these initiatives rely on a determination on the part of union officials that OSH issues should be given a greater level of importance rather than being relegated, as issues to promote, behind the more traditional 'bread and butter' concerns for improving wages and associated working conditions. Such a determination rests on providing greater resources in terms of information to members and WHSRs, and training to officials and workplace delegates. O ur study reveals some evidence of unions making strategic use of OSH to raise awareness of workplace grievances. However, our data further reveal that these initiatives are largely confined to workplaces and occupations that produce the more traditional and obvious OSH risks. In this sense, unions are not so much capitalising on new OSH opportunities - which arise in areas of emerging atypical employment, or because of the rights they enjoy under health and safety regulations - as conducting OSH business as usual. 


\section{References}

1. Walters D, N ichols T, Connor J, Tasiran A C and Cam S. The role and effectiveness of safety representatives in influencing workplace health and safety. Research report 363.

Prepared by Cardiff University for the $\mathrm{H}$ ealth and Safety Executive. Cardiff: 2005; James $P$ and Walters D. Regulating health and safety: the way forward. London: Institute of Employment Rights, 1999.

2. H asle $P$ and Petersen $\mathrm{J}$. The role of agreements between labour unions and employers in the regulation of the work environment. Policy and Practice in H ealth and Safety 2004; 2 (1): 5-25.

3. Grant D and Pringle W. Worker participation in Australia. Sydney: M cD onald Publishers, 1996: 496.

4. Bohle $P$ and $Q$ uinlan $M$. M anaging occupational health and safety: a multidisciplinary approach. M elbourne: M acmillan, 2000: 430.

5. Quinlan M. The industrial relations of occupational health and safety. In: Q uinlan M (ed). Work and health. M elbourne: M acmillan Education A ustralia, 1993: 140-170.

6. Peetz D. Brave new workplace: how individual contracts are changing our jobs. Sydney: Allen and Unwin, 2006.

7. For an in-depth review of these developments, see $Q$ uinlan $M, M$ ayhew $C$ and Bohle $P$. The global expansion of precarious employment, work disorganisation and occupational health: a review of recent research. International J ournal of H ealth Services 2001; 31 (2): 335-414.

8. Peetz D. Unions in a contrary world: the future of the Australian trade union movement. Cambridge: Cambridge University Press, 1998.

9. Freeman R and Rogers J. W hat workers want. Ithaca: Cornell University Press, 1999;

Towers B. The representation gap: change and reform in the British and American workplace. Oxford: Oxford University Press, 1997; Walters D, N ichols T, Connor J, Tasiran A C and Cam $\mathrm{S}$. The role and effectiveness of safety representatives in influencing workplace health and safety. R esearch report 363. Prepared by Cardiff University for the Health and Safety Executive. Cardiff: 2005.

10. Johnstone R, Quinlan M and Walters D. Statutory occupational health and safety workplace arrangements for the modern labour market. J ournal of Industrial R elations 2005; 47 (1): 93-117.

11. Freeman R and M edoff J. What do unions do? N ew York: Basic Books, 1984.

12. Loudoun R. Changing from 8- to 12-hour shifts: the role of consultation and participation in determining outcomes for workers' health and well-being in manufacturing. Brisbane: The University of Q ueensland, 2000 (unpublished dissertation).

13. See, for example, Quinlan M. A participatory approach to health and safety as a vehicle for achieving equity and reform at the workplace. In: Davis $E$ and Lansbury $R$ (eds). $M$ anaging together: consultation and participation in the workplace. $M$ elbourne: Longman, 1996: 41-56.

14. Walters D. Preventative services in occupational health and safety in Europe: developments and trends in the 1990s. International Journal of H ealth Services 1997; 27 (2): 247-271; Q uinlan M. Forget evidence: the demise of research involvement by N OH SC since 1996. Journal of O ccupational H ealth Safety: Australia and N ew Z ealand 2000; 16 (3): 213-227.

15. Fairbrother P. O rganize and survive: unions and health and safety - a case study of an engineering unionized workforce. Employee Relations 1996; 18 (2): 5-88.

16. Purse K. Workplace safety and microeconomic reform in Australia. In: M orris R, $M$ ortimer $D$ and Leece $P$ (eds). Workplace reform and enterprise bargaining. Sydney: H arcourt Brace, 1999: 351-363; Q uinlan M. The impact of labour market restructuring 
on occupational health and safety in industrialised societies. Economic and Industrial Democracy 1999; 20 (3): 427-460.

17. See, for example, Walters D. Workplace arrangements for O HS in the 21st century. Working paper no. 10. Canberra: N ational Research Centre for OH S R egulation, Australian N ational University, 2003; Fairbrother P. Trade unions at the crossroads. London: M ansell, 2000; Gall G. Union organizing: campaigning for trade union recognition. London: Routledge, 2003; Gospel H and Wood S. Representing workers. London: Routledge, 2003.

18. Kelly J. Rethinking industrial relations: mobilization, collectivism and long waves. London: Routledge, 1998.

19. Frick $K$ and Walters $D$. Worker representation on health and safety in small enterprises: lessons from a Sw edish approach. International Labour Review 1998; 137 (3): 367-89.

20. Walters D. Workplace arrangements for O HS in the 21st century. Working paper no. 10. Canberra: $\mathrm{N}$ ational Research Centre for OH S Regulation, Australian N ational University, 2003.

21. M arles R. Australian O HS regulation for the 21st century. The union agenda. M elbourne: ACTU, 2003. www.actu.asn.au/public/news/1063081834_6855.html.

22. James P. Wellbeing at work: an issue whose legislative time has come? Policy and Practice in H ealth and Safety 2003; 1 (2): 5-18; H asle P and Petersen J. The role of agreements between labour unions and employers in the regulation of the work environment. Policy and Practice in Health and Safety 2004; 2 (1): 5-25.

23. Walters $D$. The challenges of change for strategies on health and safety at work in the 21st century. Policy and Practice in H ealth and Safety 2005; 2 (2): 3-21.

24. Briggs C. Federal IR reform: the shape of things to come. Report commissioned by Unions N SW. Sydney: ACIR RT, 2005.

25. Deery $S$ and $M$ itchell $R$ (eds). Employment relations: individualisation and union exclusion. Sydney: Federation Press, 1999.

26. Q uinlan $M$. The impact of labour market restructuring on occupational health and safety in industrialised societies. Economic and Industrial Democracy 1999; 20 (3): 427-460.

27. Quinlan $M, M$ ayhew $C$ and Bohle $P$. The global expansion of precarious employment, work disorganisation and consequences for occupational health: a review of recent research. International Journal of H ealth Services 2001; 31 (2): 335-414; Q uinlan M and Bohle P. Contingent work and occupational safety. In: Barling J and Frone M R (eds). The psychology of workplace safety. Washington: APA (American Psychological Association) Books, 2003: 81-106.

28. Draft O ccupational Health and Safety Amendment Bill 2006. N ew South Wales Government, M ay 2006.

29. James P. Wellbeing at work: an issue whose legislative time has come? Policy and Practice in H ealth and Safety 2003; 1 (2): 5-18.

30. For evidence of this awareness in European Union strategies, see $\mathrm{H}$ asle $\mathrm{P}$ and Petersen $\mathrm{J}$. The role of agreements between labour unions and employers in the regulation of the work environment. Policy and Practice in H ealth and Safety 2004; 2 (1): 5-25. 